\title{
Comparison of Oxidative Stresses Mediated by Different Crystalline Forms and Surface Modification of Titanium Dioxide Nanoparticles
}

\author{
Karim Samy El-Said, ${ }^{1,2}$ Ehab Mostafa Ali, ${ }^{2}$ Koki Kanehira, ${ }^{3}$ and Akiyoshi Taniguchi, ${ }^{1,4}$ \\ ${ }^{1}$ Cell-Material Interaction Group, Biomaterial Unit, Nano-Bio Field, Interaction Center for Material Nanoarchitectonics (MANA), \\ National Institute for Materials Science (NIMS), Ibaraki 305-0044, Japan \\ ${ }^{2}$ Department of Chemistry, Faculty of Science, Tanta University, Tanta, Egypt \\ ${ }^{3}$ Biotechnology Group, TOTO Ltd. Research Institute, Honson 2-8-1, Chigasaki, Kanagawa 253-8577, Japan \\ ${ }^{4}$ Graduate School of Advanced Science and Engineering, Waseda University, Tokyo 169-8555, Japan
}

Correspondence should be addressed to Akiyoshi Taniguchi; taniguchi.akiyoshi@nims.go.jp

Received 5 February 2015; Accepted 30 March 2015

Academic Editor: Dongwoo Khang

Copyright (C) 2015 Karim Samy El-Said et al. This is an open access article distributed under the Creative Commons Attribution License, which permits unrestricted use, distribution, and reproduction in any medium, provided the original work is properly cited.

\begin{abstract}
Titanium dioxide nanoparticles $\left(\mathrm{TiO}_{2} \mathrm{NPs}\right)$ are manufactured worldwide for use in a wide range of applications. There are two common crystalline forms of $\mathrm{TiO}_{2}$ anatase and rutile with different physical and chemical characteristics. We previously demonstrated that an increased DNA damage response is mediated by anatase crystalline form compared to rutile. In the present study, we conjugated $\mathrm{TiO}_{2} \mathrm{NPs}$ with polyethylene glycol (PEG) in order to reduce the genotoxicity and we evaluated some oxidative stress parameters to obtain information on the cellular mechanisms of DNA damage that operate in response to TiO $\mathrm{NPs}_{2}$ different crystalline forms exposure in hepatocarcinoma cell lines (HepG2). Our results indicated a significant increase in oxidative stress

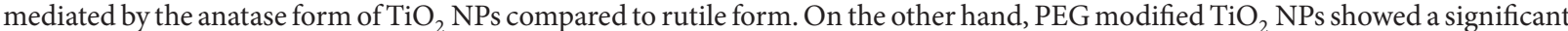
decrease in oxidative stress as compared to $\mathrm{TiO}_{2} \mathrm{NPs}$. These data suggested that the genotoxic potential of TiO $\mathrm{NPs}_{2}$ varies with crystalline form and surface modification.
\end{abstract}

\section{Introduction}

With the development of nanotechnology, there has been a tremendous growth in the application of nanoparticles (NPs) for drug delivery systems, antibacterial materials, cosmetics, sunscreens, and electronics $[1,2]$. The increased generation, use, and disposal of nanomaterial-containing products have led to an increase in the potential exposure risk to nanomaterials for both humans and the environment [3]. Titanium dioxide $\left(\mathrm{TiO}_{2}\right)$ NPs rank among the top five NPs used in consumer products [4]. $\mathrm{TiO}_{2}$ NPs are produced abundantly and used widely because of their high stability and anticorrosive and photocatalytic properties [5]. $\mathrm{TiO}_{2}$ is believed to be chemically inert. However, when the particles become progressively smaller, their surface areas, in turn, become progressively larger. Researchers have also expressed concerns about the harmful effects of $\mathrm{TiO}_{2} \mathrm{NPs}$ on human health, which are associated with this decrease in particle size $[6,7]$.

$\mathrm{TiO}_{2}$ naturally occurs in several crystalline forms, of which the most commonly found forms are anatase and rutile. The principal parameters of particles affecting their physicochemical properties include shape, size, surface characteristics, and inner structure. It has been suggested that anatase $\mathrm{TiO}_{2}$ has a greater toxic potential than rutile $\mathrm{TiO}_{2}$ $[8,9]$. The rutile form of $\mathrm{TiO}_{2}$ NPs is highly effective in the absorption of ultraviolet radiation and thus is used in sunscreens to protect against UV-induced skin damage. In contrast, the anatase form is widely used as a photocatalyst at visible or ultraviolet wavelengths [10]. The anatase form can also oxidize oxygen or organic materials directly, with active $\mathrm{TiO}_{2} \mathrm{NP}$ photocatalysis in aqueous media generating reactive 
oxygen species (ROS) such as superoxide $\left(\mathrm{O}_{2}^{-}\right)$, hydroxyl radical $\left(\mathrm{HO}^{*}\right)$, hydrogen peroxide $\left(\mathrm{H}_{2} \mathrm{O}_{2}\right)$, and singlet oxygen $[11,12]$. The excess ROS can damage cellular lipids, proteins, or DNA, thus inhibiting their normal function. Because of this, oxidative stress has been implicated in a number of human diseases, as well as in the ageing process. While ROS are products of normal cellular metabolism, they are also known to play a deleterious role in living systems [13].

Surface modification, such as coating, influences the activity of $\mathrm{TiO}_{2}$ NPs. For example, diminished cytotoxicity was observed when the surface of $\mathrm{TiO}_{2}$ NPs was modified by a "grafting-to" polymer technique combining catalytic chain transfer and thiol-ene click chemistry [14]. Polyethylene glycol (PEG) is nontoxic and nonimmunogenic and has favorable pharmacokinetics and tissue distribution [15]. PEG is a hydrophilic, nonionic polymer that exhibits excellent biocompatibility [16]. When used for drug delivery purposes, the addition of PEG to polymer particles results in increased circulation time, which in turn prevented NPs uptake by the reticuloendothelial system [17]. PEG increases hydrophilic properties and porosity and decreases crystal size and the potential for cracked film formation [18]. A water-dispersed, PEG-modified $\mathrm{TiO}_{2}$ nanoparticles exhibited photocatalytic antitumor effects in a glioma cell line [19].

In previous study, we demonstrated that an increased DNA damage response is mediated by the anatase crystalline form compared to rutile and mixed forms [20] and that PEG$\mathrm{TiO}_{2}$ NPs showed a reduction in DNA damage responses compared to $\mathrm{TiO}_{2}$ NPs [21]. We also showed that $\mathrm{TiO}_{2}$ NPs induced ROS, which are implicated in the genotoxicity induced by $\mathrm{TiO}_{2} \mathrm{NPs}$ [22]. However, the molecular mechanism of the DNA damage induced by the different crystalline forms of $\mathrm{TiO}_{2} \mathrm{NPs}$ is unknown. In this study, we explored whether the different crystalline forms of $\mathrm{TiO}_{2} \mathrm{NPs}$ cause distinct oxidative stress responses due to differences in their photocatalytic characteristics by measuring oxidative and antioxidative parameters and studied also the effect of PEG conjugation of $\mathrm{TiO}_{2}$ NPs on oxidative stress in HepG2 cells. The results indicate that the anatase form exposure induced ROS generation with increased $\mathrm{H}_{2} \mathrm{O}_{2}$, decreased glutathione peroxidase, and reduced glutathione levels more than rutile forms; this effect is followed by release of cytochrome $\mathrm{c}$ from mitochondria to cytoplasm, increased caspase-3 activity, and caused eventual DNA fragmentation and apoptosis in cells treated with $\mathrm{TiO}_{2} \mathrm{NPs}$ anatase form more than rutile forms. PEG-modified $\mathrm{TiO}_{2}$ NPs treated HepG2 cells showed a reduction in oxidative stress and apoptosis compared with cells exposed to different forms of $\mathrm{TiO}_{2}$ NPs. We anticipate that our work will advance the understanding of interactions between bionanomaterials and mammalian cells, thereby improving their application in biology and medicine.

\section{Materials and Methods}

2.1. Cells and Cell Culture. HepG2 cells were cultured in Dulbecco's Modified Eagle's Medium (DMEM, Nacalai Tesque, Inc., Kyoto, Japan) supplemented with $10 \%$ fetal bovine serum (FBS, Biowest, Nuaillé, France, UK), $100 \mathrm{U} / \mathrm{mL}$ penicillin, and $100 \mu \mathrm{g} / \mathrm{mL}$ streptomycin (Nacalai Tesque, Inc.) at $37^{\circ} \mathrm{C}$ in a humidified atmosphere containing $5 \% \mathrm{CO}_{2}$.
2.2. Preparation and Exposure to $\mathrm{TiO}_{2}$ and $P E G-\mathrm{TiO}_{2} \mathrm{NPs}$. The preparation and characterization of $\mathrm{TiO}_{2} \mathrm{NPs}$ were described in previous studies $[23,24]$. Briefly, raw titanium (IV) oxide nanoparticles of different forms (rutile, anatase, mixed rutile, and anatase) were purchased from SigmaAldrich (St. Louis, MO, USA). Mixed $\mathrm{TiO}_{2}$ samples contained approximately $80 \%$ anatase and $20 \%$ rutile form. $\mathrm{TiO}_{2} \mathrm{NPs}$ were dispersed in distilled water and autoclaved at $120^{\circ} \mathrm{C}$ for 20 min. After cooling to room temperature, the $\mathrm{TiO}_{2} \mathrm{NP}$ suspensions were sonicated for $10 \mathrm{~min}$ at $200 \mathrm{kHz}$ using a high frequency ultrasonic sonicator (MidSonic 600; Kaijo, Japan). The concentration of $\mathrm{TiO}_{2}$ NPs in the samples was determined using a UV-VIS spectrophotometer at $340 \mathrm{~nm}$ (UV-1600; Shimadzu, Kyoto, Japan). All samples were stored at $4^{\circ} \mathrm{C}$ until use. $\mathrm{TiO}_{2}$ NPs were adjusted to the desired concentration just before use by adding cell culture medium supplemented with 10\% FBS (as above). In order to characterize $\mathrm{TiO}_{2}$ NPs under cell culture conditions, the $\mathrm{TiO}_{2}$ NPs were dispersed into the culture medium and subjected to the same cell culture conditions as above. Then, particle size distribution and zeta potential of the $\mathrm{TiO}_{2} \mathrm{NP}$ solutions were measured by dynamic light scattering (Zetasizer NanoZS; Malvern Instruments, Malvern, UK). Prior to addition to the cell cultures, the suspensions of $\mathrm{TiO}_{2} \mathrm{NPs}$ were diluted in supplemented medium and used at a final concentration of $10 \mu \mathrm{g} / \mathrm{mL}$ as described above. PEG-modified $\mathrm{TiO}_{2}$ NPs (PEG$\mathrm{TiO}_{2}$ ) were prepared as described previously [19]. Specifically, $\mathrm{TiO}_{2}$ or PEG-TiO ${ }_{2}$ NPs were added to the culture medium immediately before the medium was applied to the cells. After a $48 \mathrm{~h}$ incubation period, the cells were harvested and assayed.

2.3. DCF Assay for Oxidative Stress Determination. The accumulation of intracellular free radicals from HepG2 cells exposed to different forms of $\mathrm{TiO}_{2}$ and PEG-modified $\mathrm{TiO}_{2}$ NPs was quantified using a ROS Assay Kit (OxiSelect; Cell Biolabs, Inc., San Diego, CA, USA), with the cell-permeable fluorogenic probe $2^{\prime}, 7^{\prime}$-dichlorodihydrofluorescein diacetate (DCFH-DA). DCFH-DA is a ROS detector that can cross cell membranes and be deacetylated by intracellular esterases to nonfluorescent $2^{\prime}, 7^{\prime}$-dichlorodihydrofluorescein (DCFH). In the presence of ROS, DCFH is rapidly oxidized to the highly fluorescent DCF, which is readily detectable. The fluorescence intensity is proportional to the ROS levels within the cell cytosol. HepG2 cells were cultured in 96-well black plates overnight. The cells were treated with different forms of $\mathrm{TiO}_{2}$ NPs (anatase, rutile, mixed) and PEG-TiO ${ }_{2}$ NPs for $48 \mathrm{~h}$ and were then incubated with DCHF-DA for $30 \mathrm{~min}$ at $37^{\circ} \mathrm{C}$ in the dark. Parallel sets of wells containing freshly cultured cells not treated with nanoparticles and suspended in the same concentration ratio of DPBS and DMEM were used as the negative controls. The fluorescence emission of DCF was monitored at regular intervals at an excitation wavelength of $480 \mathrm{~nm}$ and an emission wavelength of $530 \mathrm{~nm}$ using a fluorescence plate reader (Twinkle LB 970 Microplate Fluorometer; Berthold Technologies GmbH \& Co. KG, Bad Wildbad, Germany). The amount of DCF formed was calculated from a calibration curve constructed using an authentic DCF standard. 
2.4. Measurement of Glutathione Peroxidase (GPX). Glutathione peroxidase activity was measured using a Glutathione Peroxidase Assay Kit (Cayman Chemical Company, Ann Arbor, MI, USA). Cells were washed in phosphate buffer $(\mathrm{pH} 7.4)$ and collected by centrifugation $(2000 \times \mathrm{g}$ for $10 \mathrm{~min}$ at $\left.4^{\circ} \mathrm{C}\right)$. Cells were homogenized in cold assay buffer $(50 \mathrm{mM}$ Tris- $\mathrm{HCl}, \mathrm{pH}$ 7.5, $5 \mathrm{mM}$ EDTA, and $1 \mathrm{mM}$ DTT), centrifuged at $10,000 \times \mathrm{g}$ for $15 \mathrm{~min}$ at $4^{\circ} \mathrm{C}$, and the supernatant was used for the assay. Assay buffer $(100 \mu \mathrm{L}), 50 \mu \mathrm{L}$ of cosubstrate mixture, and $20 \mu \mathrm{L}$ of sample were placed in the wells of a 96well plate, and the reaction was initiated by adding $20 \mu \mathrm{L}$ of cumene hydroperoxide. The samples were thoroughly mixed by shaking and the absorbance was read at a minimum of 5 time points at $340 \mathrm{~nm}$ using a plate reader.

2.5. Measurement of Reduced Glutathione (GSH). The total glutathione concentration (reduced and oxidized forms) was determined in a microtitre plate assay using a Glutathione Assay Kit (Sigma-Aldrich). After nanoparticle exposure, HepG2 cells were washed twice with phosphate-buffered saline (PBS), resuspended in 5\% 5-sulfosalicylic acid solution, and then centrifuged at $10,000 \times \mathrm{g}$ for $10 \mathrm{~min}$. A $10 \mu \mathrm{L}$ aliquot of supernatant was mixed with $150 \mu \mathrm{L}$ of working solution and incubated for 5 minutes at room temperature, and then $50 \mu \mathrm{L}$ of diluted NADPH solution was added. The absorbance was measured at $412 \mathrm{~nm}$ using a plate reader, subtracting each reading from the reagent blank $(10 \mu \mathrm{L}$ of $5 \% 5$-sulfosalicylic acid instead of sample). The final concentration of the components in the reaction mixture was $95 \mathrm{mM}$ potassium phosphate buffer ( $\mathrm{pH}$ 7.0) containing $0.95 \mathrm{mM}$ ethylenediamine tetra-acetic acid (EDTA), $0.038 \mathrm{mg} / \mathrm{mL}(48 \mu \mathrm{M})$ $\mathrm{NADPH}, 0.031 \mathrm{mg} / \mathrm{mL}$ DTNB, 0.115 units $/ \mathrm{mL}$ glutathione reductase, and $0.24 \% 5$-sulfosalicylic acid. All measurements were performed in triplicate; GSH content (nmoles) could be calculated in the unknown samples.

2.6. Measurement of Caspase-3. A Caspase-3 Assay Kit (Colorimetric; Sigma-Aldrich) was used to assess caspase- 3 activity. HepG2 cells $\left(1 \times 10^{6}\right)$ were cultured in 6-well plates and treated as described above. At the end of the experiment, cells were washed and lysed in $100 \mu \mathrm{L}$ of lysis buffer. Next, $80 \mu \mathrm{L}$ of the sample was added to $10 \mu \mathrm{L}$ of $10 \mathrm{x}$ assay buffer and $10 \mu \mathrm{L}$ of 2 mM Ac-DEVD-pNA chromogenic substrate in the wells of a 96-well plate. Samples were incubated for 10 hours at $37^{\circ} \mathrm{C}$, and absorbance was read at $405 \mathrm{~nm}$.

2.7. Confocal Microscopy Observation. Confocal laser scanning microscopy was performed using a Zeiss LSM510 microscope (Carl Zeiss, Oberkochen, Germany). On the following day, the culture medium was replaced with medium containing the two crystalline forms of $\mathrm{TiO}_{2} \mathrm{NPs}$ (anatase or rutile) at $10 \mu \mathrm{g} / \mathrm{mL}$. Cells without NP exposure were used as controls. After a 48-h incubation, the cells were washed with PBS and fixed with $4 \%$ paraformaldehyde for $5 \mathrm{~min}$. Fixed cells were then stained for nuclei with $1 \mu \mathrm{g} / \mathrm{mL}$ Hoechst 33342 (Dojin Chemical, Tokyo Japan) for $30 \mathrm{~min}$ at $5 \% \mathrm{CO}_{2}$. Figures were created using NIH ImageJ software.

2.8. Statistical Analysis. Data were expressed as the mean \pm S.D. ( $n \geq 3$ independent experiments). The data were

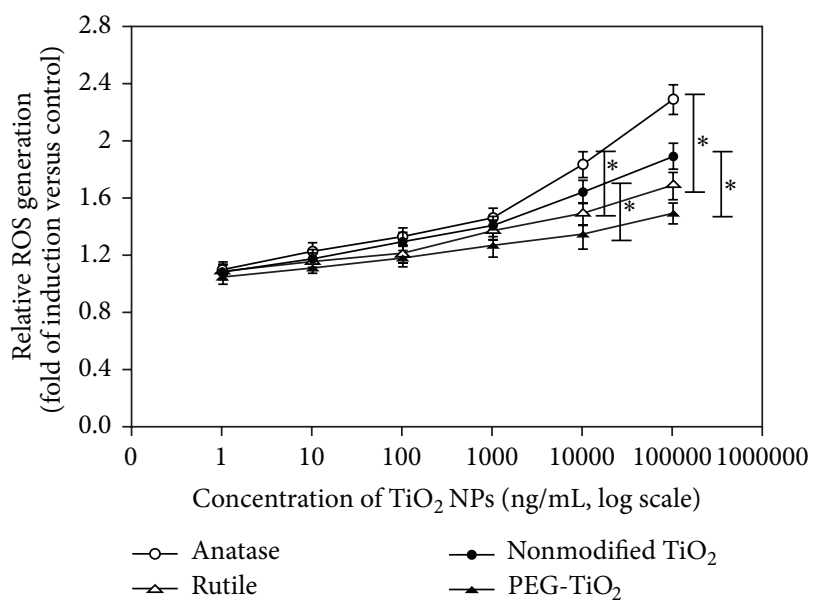

FIGURE 1: ROS generation by different crystalline forms of $\mathrm{TiO}_{2} \mathrm{NPs}$ in HepG2 cells. HepG2 cells were exposed to the anatase and rutile forms of $\mathrm{TiO}_{2} \mathrm{NPs}$, as well as nonmodified mixed crystalline $\mathrm{TiO}_{2}$ NPs (nonmodified $\mathrm{TiO}_{2}$ ) and the crystalline form of PEG modified $\mathrm{TiO}_{2}$ NPs $\left(\mathrm{PEG}-\mathrm{TiO}_{2}\right.$ ). Cells were exposed to the $\mathrm{TiO}_{2} \mathrm{NPs}$ for $48 \mathrm{~h}$ at the indicated concentrations. The results are normalized to values obtained from control HepG2 cells without NP exposure. Each plot was produced from triplicate measurements, with values presented as mean \pm S.D. $\left({ }^{*} P<0.05\right)$.

analyzed using one-way analysis of variance (ANOVA) to evaluate the statistical differences and multicomparison between treated and control cells. Statistical significance was accepted at $P<0.05$.

\section{Results and Discussion}

3.1. ROS Generation by Different Forms of $\mathrm{TiO}_{2} \mathrm{NPs}$. In the present study, we compared the oxidative stress induced by the different crystalline forms of $\mathrm{TiO}_{2} \mathrm{NPs}$ (anatase and rutile) and different surface forms, that is, nonmodified mixed crystalline form (nonmodified $\mathrm{TiO}_{2}$ ) and PEGmodified mixed crystalline form $\left(\mathrm{PEG}-\mathrm{TiO}_{2}\right)$ of $\mathrm{TiO}_{2} \mathrm{NPs}$. HepG2 cells were exposed to the various $\mathrm{TiO}_{2}$ NPs and ROS generation was evaluated according to dose dependency (Figure 1) and time (Figure 2). We used different concentrations of NPs ranging from $1 \mathrm{ng} / \mathrm{mL}$ to $100 \mu \mathrm{g} / \mathrm{mL}$ and exposure times ranging from $3 \mathrm{~h}$ to $48 \mathrm{~h}$. Cells not exposed to NPs were used as controls. Our results showed that $\mathrm{TiO}_{2} \mathrm{NPs}^{-}$ induced ROS were generated in a dose-dependent manner. At low NPs concentrations (1 to $1000 \mathrm{ng} / \mathrm{mL}$ ), significant levels of ROS were not generated in response to NPs exposure. However, cells treated with 10 and $100 \mu \mathrm{g} / \mathrm{mL}$ of anatase $\mathrm{TiO}_{2}$ NPs showed a significant increase in ROS generation as compared to cells treated with rutile form of $\mathrm{TiO}_{2} \mathrm{NPs}$. Changing the surface characters of $\mathrm{TiO}_{2}$ NPs by coating with PEG $\left(\mathrm{PEG}-\mathrm{TiO}_{2}\right)$ showed significantly less ROS generation when compared with the nonmodified mixed form of $\mathrm{TiO}_{2}$ NPs (nonmodified $\mathrm{TiO}_{2}$ ) as shown in Figure 1.

Figure 2 shows the time course of ROS generation following treatment with the different types of $\mathrm{TiO}_{2} \mathrm{NPs}$; the concentration of NPs was standardized at $10 \mu \mathrm{g} / \mathrm{mL}$. At $48 \mathrm{~h}$ of NPs exposure, each NP caused a significant increase in 


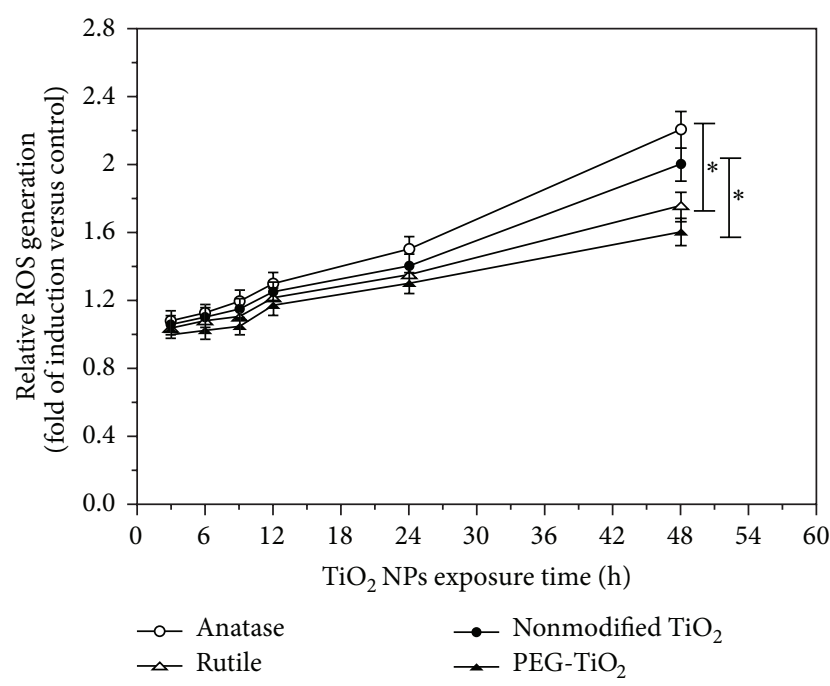

FIGURE 2: Time course of ROS generation in HepG2 cells exposed to different types of $\mathrm{TiO}_{2}$ NPs. The cells were exposed to NPs $(10 \mu \mathrm{g} / \mathrm{mL})$ for the indicated durations. The results are normalized to values obtained from control HepG2 cells without NP exposure. Each plot was produced from triplicate measurements, with values presented as mean \pm S.D. $\left({ }^{*} P<0.05\right)$.

ROS generation; cells exposed to anatase $\mathrm{TiO}_{2} \mathrm{NPs}$ forms showed a 2.2-fold increase, while cells exposed to rutile $\mathrm{TiO}_{2}$ NPs showed an approximately 1.75 -fold increase. The nonmodified $\mathrm{TiO}_{2}$ NPs mixed forms exposed cells exhibited 2 -fold increase and the PEG-TiO ${ }_{2}$ NPs treated cells showed 1.6-fold increase in ROS generation compared to the control cells. There was no effective change on the ROS generation of HepG2 cells when exposed to shorter times to NPs. These results indicate that cells treated with anatase form exhibited significantly more ROS generation when compared with cells treated with the rutile form and that PEG modification causes a significant decrease in ROS generated by mixed $\mathrm{TiO}_{2} \mathrm{NPs}$. Therefore, the crystalline form and surface characters of $\mathrm{TiO}_{2}$ NPs are an important point to investigate when studying the interaction of the nanomaterials with cells.

3.2. Oxidative Stress Determinations. Oxidative stress is described as the deregulation of oxidants and antioxidants, which is associated with several diseases. Hydrogen peroxide $\left(\mathrm{H}_{2} \mathrm{O}_{2}\right)$ is a main ROS that is produced endogenously by several physiological processes, such as the inflammatory respiratory burst and during oxidative phosphorylation. ROS, including $\mathrm{H}_{2} \mathrm{O}_{2}$, also participate in pathway signaling related to cellular proliferation, migration, and apoptosis [25]. Figure 3 shows $\mathrm{H}_{2} \mathrm{O}_{2}$ induction by different types of $\mathrm{TiO}_{2}$ NPs exposure. HepG2 cells exposed to the anatase form showed an approximately 2-fold significant increase in $\mathrm{H}_{2} \mathrm{O}_{2}$ levels (reaching $165 \mathrm{nmol} / \mathrm{mL}$ ) compared to control cells. The cells exposed to rutile $\mathrm{TiO}_{2} \mathrm{NP}$ generated $138 \mathrm{nmol} / \mathrm{mL}$ of $\mathrm{H}_{2} \mathrm{O}_{2}$, an approximately 1.7 -fold significant increase when compared to control cells, and the $\mathrm{H}_{2} \mathrm{O}_{2}$ level in cells exposed to nonmodified $\mathrm{TiO}_{2} \mathrm{NPs}$ mixed form was $150 \mathrm{nmol} / \mathrm{mL}$, an approximately 1.8 -fold significant increase compared to

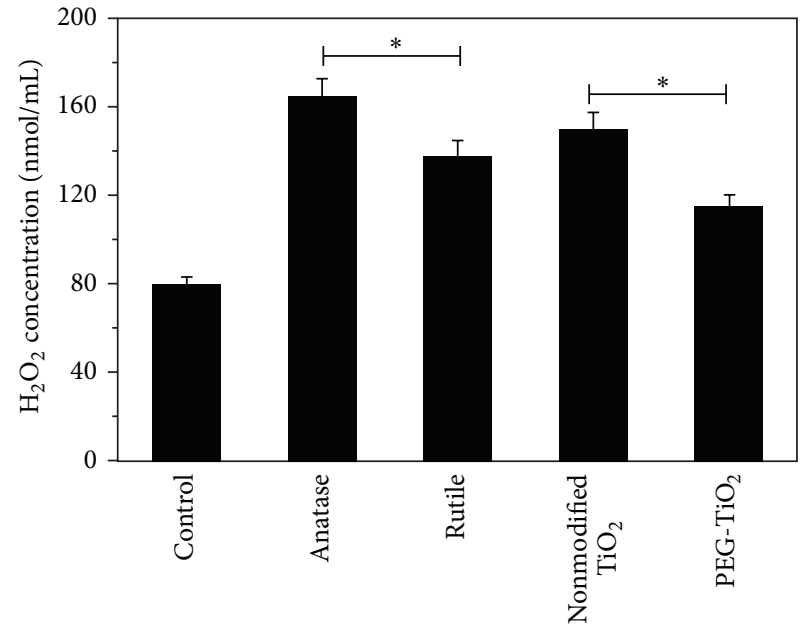

Figure 3: Measurement of $\mathrm{H}_{2} \mathrm{O}_{2}$ concentrations in HepG2 cells exposed to different types of $\mathrm{TiO}_{2}$ NPs. Cells were exposed to individual NPs $(10 \mu \mathrm{g} / \mathrm{mL})$ for $48 \mathrm{~h}$. HepG2 cells without NP exposure are shown as control. Each plot was produced from triplicate measurements, with values presented as mean \pm S.D. $\left({ }^{*} P<0.05\right)$.

control cells. PEG-TiO ${ }_{2}$ NPs exposed cells showed a significant decrease in $\mathrm{H}_{2} \mathrm{O}_{2}$ levels $(115 \mathrm{nmol} / \mathrm{mL})$ compared with nonmodified mixed forms of $\mathrm{TiO}_{2} \mathrm{NPs}$; the one-way analysis of variance (ANOVA) and multicomparison between all treated cells and control cells showed that the variation of means is significantly increased and $P$ value is less than 0.05. The data suggested that HepG2 cells exposed to $\mathrm{TiO}_{2}$ $\mathrm{NP}$ showed $\mathrm{H}_{2} \mathrm{O}_{2}$-induced oxidative stress, and exposure to anatase $\mathrm{TiO}_{2}$ NPs caused significantly higher responses to $\mathrm{H}_{2} \mathrm{O}_{2}$-induced oxidative stress than rutile $\mathrm{TiO}_{2} \mathrm{NPs}$ forms exposure and PEG modification of $\mathrm{TiO}_{2}$ NPs protected HepG2 cells against $\mathrm{H}_{2} \mathrm{O}_{2}$-induced oxidative stress.

Antioxidant activities in HepG2 cells exposed to different types of $\mathrm{TiO}_{2}$ NPs were evaluated by measuring GPX activity and GSH levels. GPX is the enzyme that catalyzes the reduction of hydroperoxides, including $\mathrm{H}_{2} \mathrm{O}_{2}$. GPX activity and GSH levels were evaluated to elucidate the mechanism of $\mathrm{H}_{2} \mathrm{O}_{2}$ detoxification during exposure to different types of $\mathrm{TiO}_{2}$ NPs. The results indicate that cells exposed to anatase, rutile, and nonmodified $\mathrm{TiO}_{2} \mathrm{NPs}$ exhibited 38, 50, and $40 \mathrm{nmol} / \mathrm{min} / \mathrm{mL}$ of GPX activity, respectively. HepG2 cells treated with anatase $\mathrm{TiO}_{2}$ NPs showed significantly less GPX activity, indicating increased oxidative stress compared to cells exposed to the rutile forms. Cells exposed to PEG-TiO 2 exhibited a significantly more GPX activity $(58 \mathrm{nmol} / \mathrm{min} / \mathrm{mL})$, indicating retention of antioxidant capacity (Figure 4). The multicomparison data between all treated cells and control showed significant changes except cells exposed to anatase versus cells exposed to nonmodified $\mathrm{TiO}_{2}$ NPs which showed nonsignificant change with $P$ value greater than 0.05 .

Similarly, HepG2 cells exposed to $\mathrm{TiO}_{2} \mathrm{NP}$ exhibited reduced GSH levels. Specifically, cells exposed to anatase $\mathrm{TiO}_{2}$ NPs exhibited significantly decreased GSH levels compared to cells treated with rutile forms. PEG-TiO ${ }_{2} \mathrm{NPs}$ 


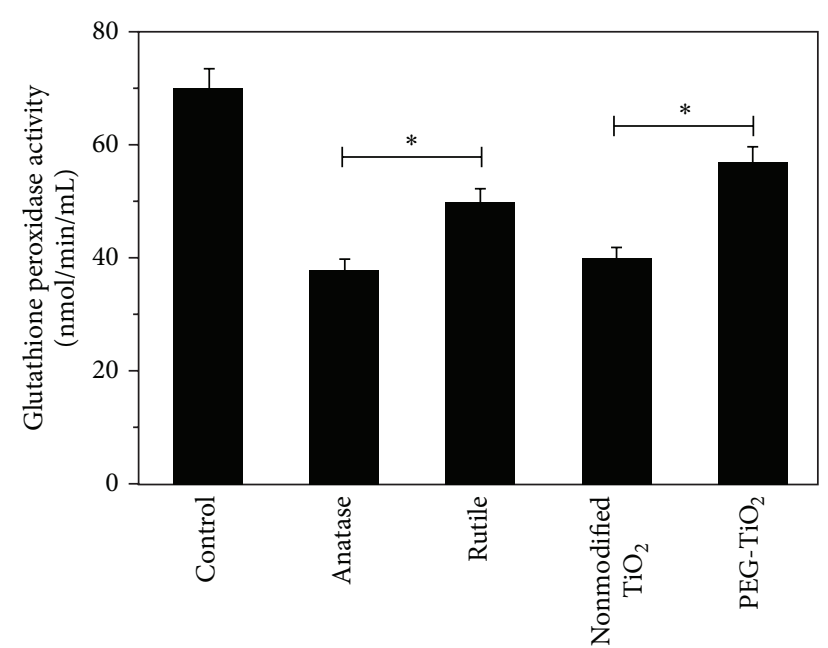

Figure 4: GPx activities in HepG2 cells exposed to different types of $\mathrm{TiO}_{2}$ NPs. Cells were exposed to individual NPs $(10 \mu \mathrm{g} / \mathrm{mL})$ for $48 \mathrm{~h}$. Control values represent HepG2 cells without NP exposure. Each plot was produced from triplicate measurements, with values presented as mean \pm S.D. $\left({ }^{*} P<0.05\right)$.

appeared to reduce the effects of $\mathrm{TiO}_{2} \mathrm{NP}$ exposure and increased GSH levels (Figure 5). Statistical analysis of GSH data and comparison between cells showed that significant changes between cells only were observed in control versus anatase exposed cells ${ }^{* * *} P<0.001$, control versus rutile ${ }^{* *} P<0.01$, control versus nonmodified ${ }^{* *} P<0.01$, and anatase versus PEG-modified treated cells ${ }^{*} P<0.05$. These results suggest that the antioxidant GSH is involved in $\mathrm{H}_{2} \mathrm{O}_{2}$ detoxification following $\mathrm{TiO}_{2}$ NPs exposure and that anatase $\mathrm{TiO}_{2}$ produces greater oxidative stress than rutile $\mathrm{TiO}_{2}$, as evidenced by their effects on GSH levels.

3.3. Assessments of Oxidative Stress-Induced Apoptosis. Caspase-3 is an effector cysteine protease that is involved in apoptosis and necrosis and is activated by $\mathrm{H}_{2} \mathrm{O}_{2}$ [26]. Caspase3 activity was measured to evaluate the apoptotic responses to oxidative stress occurring in HepG2 cells exposed to different forms of $\mathrm{TiO}_{2} \mathrm{NPs}$. Our results showed a significant increase in caspase-3 activity, which is a critical apoptotic enzyme, as well as DNA fragmentation, in cells exposed to anatase $\mathrm{TiO}_{2} \mathrm{NPs}(3.2$ and $2.5 \mathrm{nmol} / \mathrm{min} / \mathrm{mL}$ in anatase and rutile NPs, resp.). Nonmodified $\mathrm{TiO}_{2} \mathrm{NP}$ exposure produced $2.7 \mathrm{nmol} / \mathrm{min} / \mathrm{mL}$ of caspase- 3 activity, while PEG-TiO ${ }_{2} \mathrm{NP}-$ treatment resulted in $2.1 \mathrm{nmol} / \mathrm{min} / \mathrm{mL}$, which is virtually the same as the control value of $2 \mathrm{nmol} / \mathrm{min} / \mathrm{mL}$ (Figure 6). The significant changes between cells were observed in control versus anatase ${ }^{* *} P<0.01$, anatase versus rutile ${ }^{*} P<0.05$, and anatase versus PEG-modified treated cells ${ }^{* *} P<0.001$. Therefore, anatase $\mathrm{TiO}_{2}$ NPs produced significantly greater apoptotic responses than the rutile form in HepG2 cells.

The induction of apoptosis in HepG2 cells exposed to the two common crystalline forms of $\mathrm{TiO}_{2}$ NPs was confirmed by observing apoptotic cells using confocal microscopy. We used Hoechst DNA staining to observe nuclear fragmentation as an indication of apoptosis. The morphological

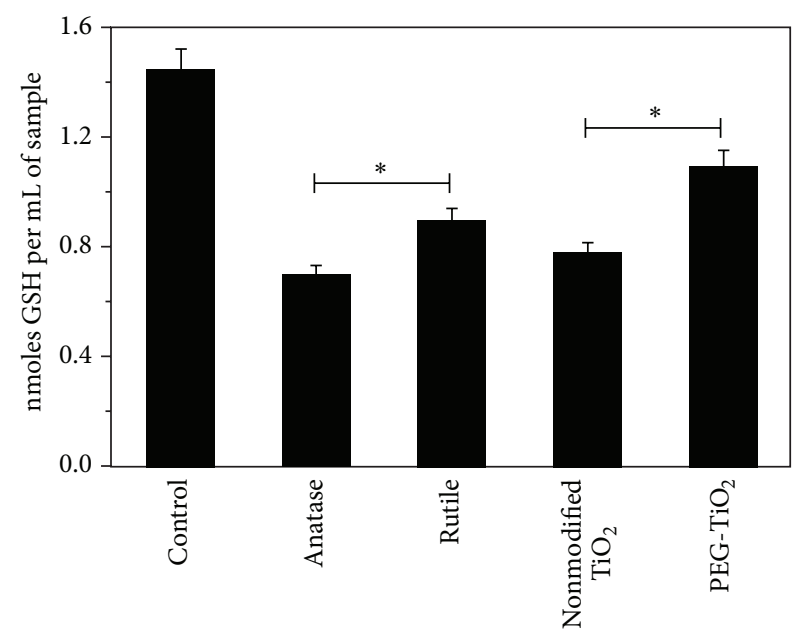

FIGURE 5: GSH levels in HepG2 cells exposed to different types of $\mathrm{TiO}_{2}$ NPs. Cells were exposed to individual NPs $(10 \mu \mathrm{g} / \mathrm{mL})$ for $48 \mathrm{~h}$. Control values represent HepG2 cells without NP exposure. Each plot was produced from triplicate measurements, with values presented as mean \pm S.D. $\left({ }^{*} P<0.05\right)$.

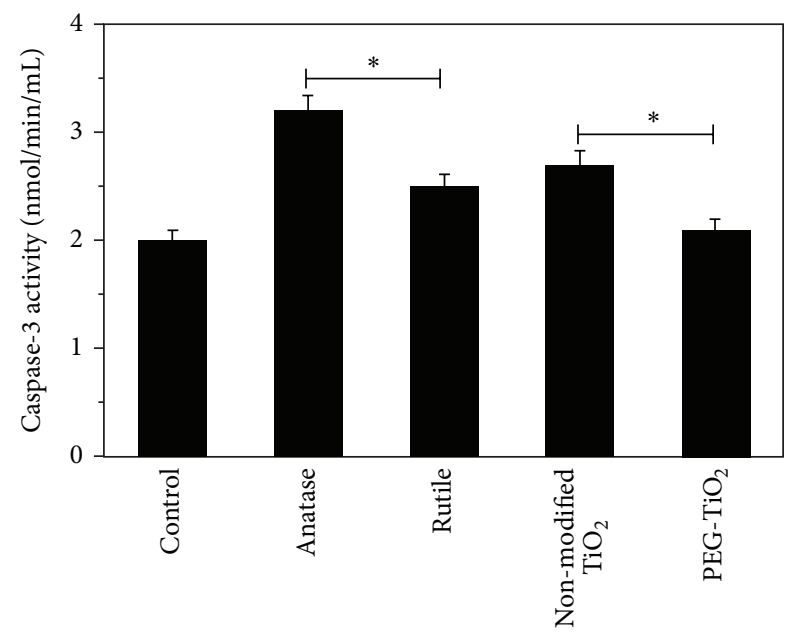

FIgURE 6: Caspase-3 activity in HepG2 cells exposed to different types of $\mathrm{TiO}_{2}$ NPs. Cells were exposed to individual NPs $(10 \mu \mathrm{g} / \mathrm{mL})$ for $48 \mathrm{~h}$. Control values represent HepG2 cells without NP exposure. Each plot was produced from triplicate measurements, with values presented as mean \pm S.D. $\left({ }^{*} P<0.05\right)$.

changes observed include condensation of chromatin and nuclear fragmentation, as shown in Figure 7. The microscopy analysis confirmed that cells exposed to $\mathrm{TiO}_{2} \mathrm{NPs}$ undergo programmed cell death (apoptosis) due to DNA damage. Enumeration of apoptotic HepG2 cells in the absence of $\mathrm{TiO}_{2}$ NPs revealed the percentage of cells with nuclear fragmentation to be $30 \%$ (Figure $7(\mathrm{a})$ ), while $71 \%$ of HepG2 cells exposed to crystalline anatase $\mathrm{TiO}_{2}$ NPs (Figure 7(b)) and $59 \%$ of cells exposed to rutile $\mathrm{TiO}_{2} \mathrm{NPs}$ were apoptotic (Figure $7(\mathrm{c})$ ). The results indicate that the crystalline anatase $\mathrm{TiO}_{2}$ NPs induce a greater degree of apoptotic cell death compared with the rutile form. 


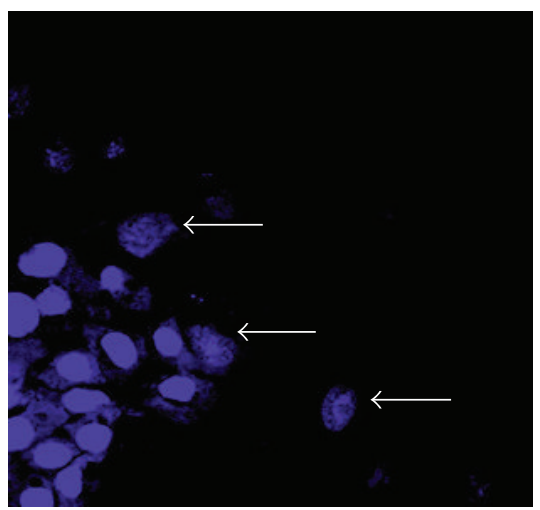

(a)

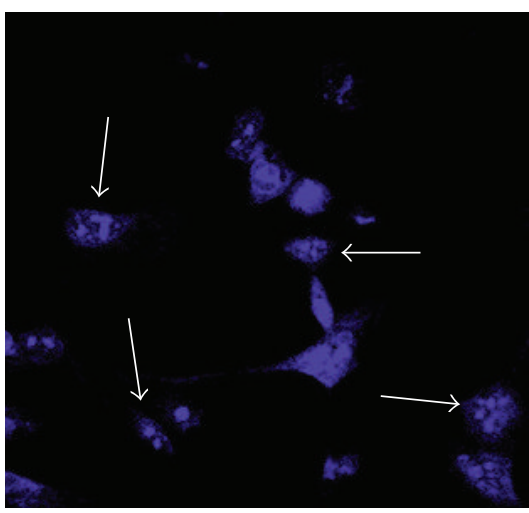

(b)

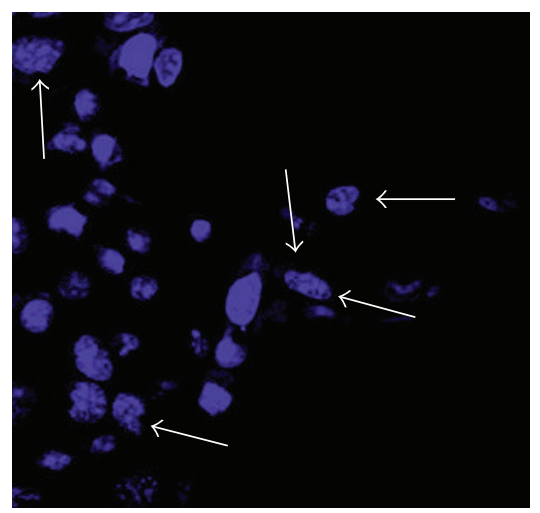

(c)

Figure 7: Confocal laser scanning microscopic images of HepG2 cells exposed to $\mathrm{TiO}_{2} \mathrm{NPs}$. The confocal microscopic images show condensation of chromatin and nuclear fragmentation in HepG2 cells exposed to different crystalline forms of TiO 2 NPs. (a) Control HepG2 cells without $\mathrm{TiO}_{2} \mathrm{NPs}$ exposure; (b) cells exposed to $10 \mu \mathrm{g} / \mathrm{mL}$ crystalline anatase $\mathrm{TiO}_{2} \mathrm{NPs}_{\text {for }} 48 \mathrm{~h}$; (c) cells exposed to $10 \mu \mathrm{g} / \mathrm{mL} \mathrm{crystalline}$ rutile $\mathrm{TiO}_{2} \mathrm{NPs}$ for $48 \mathrm{~h}$. The white arrows indicate apoptotic cells with nuclear fragmentation.

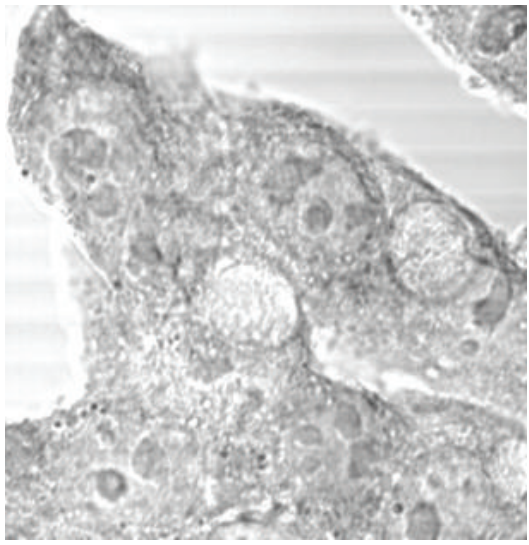

(a)

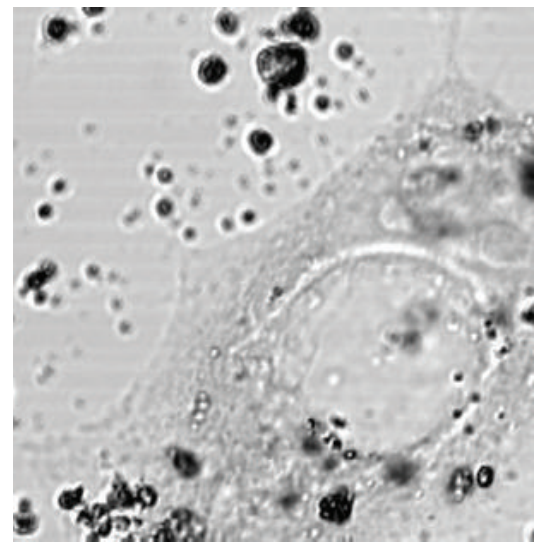

(b)

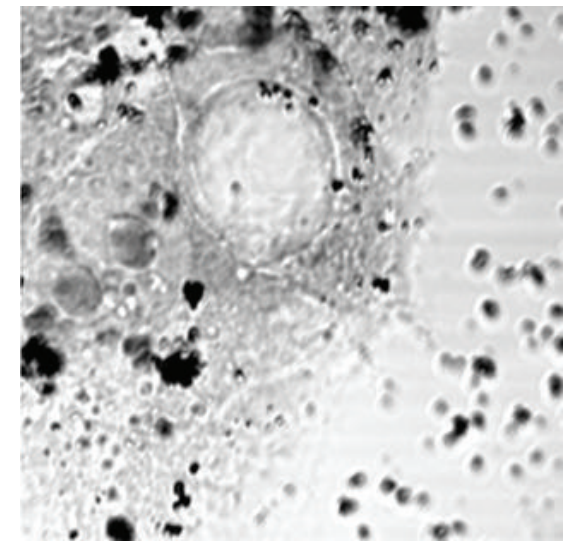

(c)

Figure 8: Localization of crystalline anatase and rutile $\mathrm{TiO}_{2} \mathrm{NPs}$ in HepG2 cells. Confocal microscopy of reflection images was used also to verify the location of $\mathrm{TiO}_{2} \mathrm{NPs}$ in HepG2 cells. (a) Control HepG2 cells without $\mathrm{TiO}_{2} \mathrm{NP}$ exposure; (b) cells exposed to $10 \mu \mathrm{g} / \mathrm{mL}$ crystalline anatase $\mathrm{TiO}_{2} \mathrm{NPs}$ for $48 \mathrm{~h}$; (c) cells exposed to $10 \mu \mathrm{g} / \mathrm{mL}$ crystalline rutile $\mathrm{TiO}_{2} \mathrm{NPs}$ for $48 \mathrm{~h}$.

Confocal microscopy was used also to verify the location of $\mathrm{TiO}_{2}$ NPs in HepG2 cells. The images revealed that anatase and rutile $\mathrm{TiO}_{2}$ NPs were internalized by HepG2 cells to a similar degree (Figures $8(\mathrm{~b})$ and $8(\mathrm{c})$ ), when compared to control cells (Figure 8(a)). These results indicate that both crystalline forms of $\mathrm{TiO}_{2}$ NPs were incorporated by HepG2 cells to the same extent.

\section{Discussion}

Generally, anatase is more reactive than rutile. Anatase differs from rutile in cleavage and the overall visible external shape because of structural differences. Although both forms are tetragonal, the different crystalline forms give rise to different physical and chemical characteristics such as hardness, refractive index, and photocatalytic ability. In the present study, we compared the effects of the anatase and rutile crystalline forms of $\mathrm{TiO}_{2} \mathrm{NPs}$ on cellular oxidative stress and apoptosis in HepG2 cells. One of the most discussed mechanisms underlying the biological effects of ambient particles is their ability to cause oxidative stress. The interactions of NPs with cell membranes result in the generation of ROS, and the resulting oxidative stress may cause a degradation of membrane lipids, an imbalance of intracellular calcium homeostasis, and DNA breakage $[27,28]$, which is considered an underlying molecular mechanism implicated in the cytotoxic, inflammatory, and DNA damaging effects of nanoparticles. Our results showed that anatase $\mathrm{TiO}_{2}$ has a greater ROS potential (mainly $\mathrm{H}_{2} \mathrm{O}_{2}$ ) than rutile $\mathrm{TiO}_{2}$.

Our study showed greater inhibition of GPX activity and GSH levels in HepG2 cells exposed to anatase $\mathrm{TiO}_{2}$ than the rutile form. GPX and GSH are antioxidants used in the detoxification of $\mathrm{H}_{2} \mathrm{O}_{2}$ and their inhibition confirms the retention of $\mathrm{H}_{2} \mathrm{O}_{2} \cdot \mathrm{H}_{2} \mathrm{O}_{2}$ is a natural source of oxidative damage in 
cells, causing a spectrum of DNA lesions, including single and double strand breaks [29]. DNA damage due to $\mathrm{H}_{2} \mathrm{O}_{2}$ results from the production of the hydroxyl radical $\left({ }^{\circ} \mathrm{OH}\right)$ in the presence of transition metal ions, such as iron, via the Fenton reaction. $\mathrm{H}_{2} \mathrm{O}_{2}$ can cause oxidative stress because it uses water channels to rapidly cross cell membranes and reach the nucleus where it can damage DNA. Caspases are a family of proteases that regulate cell death and are important mediators of apoptosis. Caspase- 3 is a critical effector caspase that plays a central role in initiating nuclear apoptosis, including chromatin condensation, DNA fragmentation, and blebbing [30]. Our results showed a significant increase in caspase-3 activity in HepG2 cells exposed to anatase $\mathrm{TiO}_{2}$ NPs and to a lesser degree by exposure to the rutile form. We hypothesized that the two forms of $\mathrm{TiO}_{2}$ NPs would elicit different cellular oxidative stress responses because, compared to rutile, anatase has a lighter average effective mass of photogenerated electrons and holes. The lighter effective mass suggests that anatase $\mathrm{TiO}_{2}$ particles exhibit faster migration of electrons and holes from the interior to its surface and hence greater ROS generation, compared to rutile [31]. Our results support the contention that there is no difference in the cellular incorporation of anatase and rutile $\mathrm{TiO}_{2}$ NPs. Therefore, the differences in genotoxicity induced by the two crystalline forms of $\mathrm{TiO}_{2}$ NPs were due to differences in the generation of oxidative stress, which initiates DNA damage and apoptosis in HepG2 cells.

One strategy to prevent the genotoxicity of $\mathrm{TiO}_{2}$ nanoformulations is through the use of a PEG coating. Modifying the surface of NPs with PEG prevents agglomeration [32], renders NPs resistant to protein adsorption, and enhances their biocompatibility [33]. We conjugated the $\mathrm{TiO}_{2} \mathrm{NPs}$ with PEG to examine whether $\mathrm{TiO}_{2}$ NP-induced oxidative stress was altered. The present results showed that ROS generation was reduced following PEG modification, as evidenced by reduced levels of $\mathrm{H}_{2} \mathrm{O}_{2}$, preservation of GPX and GSH levels, and decreased caspase-3 activation, thus confirming the decreased DNA damage and oxidative stressinduced apoptosis in HepG2 cells exposed to PEG-TiO 2 NPs compared to cells exposed to $\mathrm{TiO}_{2}$ NPs.

\section{Conclusions}

Our results showed that HepG2 cells treated with different types of $\mathrm{TiO}_{2}$ NPs produced distinct oxidative stress responses by affecting the oxidative balance. Specifically, exposure to anatase $\mathrm{TiO}_{2} \mathrm{NPs}$ produced significantly greater ROS formation, oxidative stress responses, and apoptosis, when compared to rutile $\mathrm{TiO}_{2}$ NPs. Furthermore, modification of $\mathrm{TiO}_{2}$ NPs with PEG showed decreased oxidative stress and apoptosis in HepG2 cells, thereby confirming the reduction of ROS induced by $\mathrm{TiO}_{2}$ NPs. Therefore, exposure of HepG2 cells to $\mathrm{TiO}_{2} \mathrm{NP}$ causes an elevation in ROS levels and downregulates ROS scavengers associated with protection from DNA damage and apoptosis. Furthermore, anatase forms mediated these events to a greater degree than rutile forms of $\mathrm{TiO}_{2} \mathrm{NPs}$.

\section{Conflict of Interests}

The authors declare that they have no conflict of interests.

\section{Acknowledgment}

This work was supported by Interaction Center for Material Nanoarchitectonics (MANA), National Institute for Materials Science (NIMS), Japan.

\section{References}

[1] E. R. Kisin, A. R. Murray, M. J. Keane et al., "Single-walled carbon nanotubes: geno- and cytotoxic effects in lung fibroblast V79 cells," Journal of Toxicology and Environmental Health Part A: Current Issues, vol. 70, no. 24, pp. 2071-2079, 2007.

[2] T. A. Robertson, W. Y. Sanchez, and M. S. Roberts, "Are commercially available nanoparticles safe when applied to the skin?" Journal of Biomedical Nanotechnology, vol. 6, no. 5, pp. 452-468, 2010.

[3] M. S. Olson and P. L. Gurian, "Risk assessment strategies as nanomaterials transition into commercial applications," Journal of Nanoparticle Research, vol. 14, no. 4, article 786, 2012.

[4] R. K. Shukla, V. Sharma, A. K. Pandey, S. Singh, S. Sultana, and A. Dhawan, "ROS-mediated genotoxicity induced by titanium dioxide nanoparticles in human epidermal cells," Toxicology in Vitro, vol. 25, no. 1, pp. 231-241, 2011.

[5] J. Riu, A. Maroto, and F. X. Rius, "Nanosensors in environmental analysis," Talanta, vol. 69, no. 2, pp. 288-301, 2006.

[6] C. Wang and $\mathrm{Y}$. $\mathrm{Li}$, "Interaction and nanotoxic effect of $\mathrm{TiO}_{2}$ nanoparticle on fibrinogen by multi-spectroscopic method," Science of the Total Environment, vol. 429, pp. 156-160, 2012.

[7] P. O. Andersson, C. Lejon, B. Ekstrand-Hammarström et al., "Polymorph- and size-dependent uptake and toxicity of $\mathrm{TiO}_{2}$ nanoparticles in living lung epithelial cells," Small, vol. 7, no. 4, pp. 514-523, 2011.

[8] C. Xue, J. Wu, F. Lan et al., "Nano titanium dioxide induces the generation of ROS and potential damage in HaCaT cells under UVA irradiation," Journal of Nanoscience and Nanotechnology, vol. 10, no. 12, pp. 8500-8507, 2010.

[9] J. Petković, B. Žegura, M. Stevanović et al., "DNA damage and alterations in expression of DNA damage responsive genes induced by $\mathrm{TiO}_{2}$ nanoparticles in human hepatoma HepG2 cells," Nanotoxicology, vol. 5, no. 3, pp. 341-353, 2011.

[10] M. E. Kurtoglu, T. Longenbach, and Y. Gogotsi, "Preventing sodium poisoning of photocatalytic $\mathrm{TiO}_{2}$ films on glass by metal doping," International Journal of Applied Glass Science, vol. 2, no. 2, pp. 108-116, 2011.

[11] J. C. Ireland, P. Klostermann, E. W. Rice, and R. M. Clark, "Inactivation of Escherichia coli by titanium dioxide photocatalytic oxidation," Applied and Environmental Microbiology, vol. 59, no. 5, pp. 1668-1670, 1993.

[12] R. Konaka, E. Kasahara, W. C. Dunlap, Y. Yamamoto, K. C. Chien, and M. Inoue, "Ultraviolet irradiation of titanium dioxide in aqueous dispersion generates singlet oxygen," Redox Report, vol. 6, no. 5, pp. 319-325, 2001.

[13] M. Valko, C. J. Rhodes, J. Moncol, M. Izakovic, and M. Mazur, "Free radicals, metals and antioxidants in oxidative stressinduced cancer," Chemico-Biological Interactions, vol. 160, no. 1, pp. 1-40, 2006. 
[14] R. Tedja, M. Lim, R. Amal, and C. Marquis, "Effects of serum adsorption on cellular uptake profile and consequent impact of titanium dioxide nanoparticles on human lung cell lines," ACS Nano, vol. 6, no. 5, pp. 4083-4093, 2012.

[15] W. Wang, W. Xiong, J. Wan, X. Sun, H. Xu, and X. Yang, "The decrease of PAMAM dendrimer-induced cytotoxicity by PEGylation via attenuation of oxidative stress," Nanotechnology, vol. 20, no. 10, Article ID 105103, 2009.

[16] J. V. Jokerst, T. Lobovkina, R. N. Zare, and S. S. Gambhir, "Nanoparticle PEGylation for imaging and therapy," Nanomedicine, vol. 6, no. 4, pp. 715-728, 2011.

[17] G. B. Jacobson, E. Gonzalez-Gonzalez, R. Spitler et al., "Biodegradable nanoparticles with sustained release of functional siRNA in skin," Journal of Pharmaceutical Sciences, vol. 99, no. 10, pp. 4261-4266, 2010.

[18] T. Miki, K. Nishizawa, K. Suzuki, and K. Kato, "Preparation of thick $\mathrm{TiO}_{2}$ film with large surface area using aqueous sol with poly(ethylene glycol)," Journal of Materials Science, vol. 39, no. 2, pp. 699-701, 2004.

[19] S. Yamaguchi, H. Kobayashi, T. Narita et al., "Sonodynamic therapy using water-dispersed $\mathrm{TiO}_{2}$-polyethylene glycol compound on glioma cells: comparison of cytotoxic mechanism with photodynamic therapy," Ultrasonics Sonochemistry, vol. 18, no. 5, pp. 1197-1204, 2011.

[20] P. Chen and A. Taniguchi, "Detection of DNA damage response caused by different forms of titanium dioxide nanoparticles using sensor cells," Journal of Biosensors \& Bioelectronics, vol. 3, article 129, 2012.

[21] K. S. El-Said, E. M. Ali, K. Kanehira, and A. Taniguchi, "Effects of toll-like receptors 3 and 4 induced by titanium dioxide nanoparticles in DNA damage-detecting sensor cells," Journal of Biosensors \& Bioelectronics, vol. 4, article 144, 2013.

[22] K. El-Said, E. Ali, K. Kanehira, and A. Taniguchi, "Molecular mechanism of DNA damage induced by titanium dioxide nanoparticles in toll-like receptor 3 or 4 expressing human hepatocarcinoma cell lines," Journal of Nanobiotechnology, vol. 12, article 48, 2014.

[23] P. Chen, S. Migita, K. Kanehira, S. Sonezaki, and A. Taniguchi, "Development of sensor cells using NF- $\kappa$ B pathway activation for detection of nanoparticle-induced inflammation," Sensors, vol. 11, no. 7, pp. 7219-7230, 2011.

[24] P. Chen, K. Kanehira, S. Sonezaki, and A. Taniguchi, "Detection of cellular response to titanium dioxide nanoparticle agglomerates by sensor cells using heat shock protein promoter," Biotechnology and Bioengineering, vol. 109, no. 12, pp. 3112-3118, 2012.

[25] M. R. Brown, F. J. Miller Jr., W.-G. Li et al., "Overexpression of human catalase inhibits proliferation and promotes apoptosis in vascular smooth muscle cells," Circulation Research, vol. 85, no. 6, pp. 524-533, 1999.

[26] S. M. Piperakis, K. Kontogianni, G. Karanastasi, Z. IakovidouKritsi, and M. M. Piperakis, "The use of comet assay in measuring DNA damage and repair efficiency in child, adult, and old age populations," Cell Biology and Toxicology, vol. 25, no. 1, pp. 65-71, 2009.

[27] J. M. Petruska, K. O. Leslie, and B. T. Mossman, "Enhanced lipid peroxidation in lung lavage of rats after inhalation of asbestos," Free Radical Biology and Medicine, vol. 11, no. 4, pp. 425-432, 1991.

[28] R. K. Shukla, A. Kumar, A. K. Pandey, S. S. Singh, and A. Dhawan, "Titanium dioxide nanoparticles induce oxidative stress-mediated apoptosis in human keratinocyte cells," Journal of Biomedical Nanotechnology, vol. 7, no. 1, pp. 100-101, 2011.

[29] A. R. Collins, "Oxidative DNA damage, antioxidants, and cancer," BioEssays, vol. 21, no. 3, pp. 238-246, 1999.

[30] A. G. Porter and R. U. Jänicke, "Emerging roles of caspase-3 in apoptosis," Cell Death and Differentiation, vol. 6, no. 2, pp. 99104, 1999.

[31] J. Zhang, P. Zhou, J. Liu, and J. Yu, "New understanding of the difference of photocatalytic activity among anatase, rutile and brookite $\mathrm{TiO}_{2}$," Physical Chemistry Chemical Physics, vol. 16, pp. 20382-20386, 2014.

[32] S. Matsumura, S. Sato, M. Yudasaka et al., "Prevention of carbon nanohorn agglomeration using a conjugate composed of combshaped polyethylene glycol and a peptide aptamer," Molecular Pharmaceutics, vol. 6, no. 2, pp. 441-447, 2009.

[33] W. Eck, G. Craig, A. Sigdel et al., "PEGylated gold nanoparticles conjugated to monoclonal F19 antibodies as targeted labeling agents for human pancreatic carcinoma tissue," ACS Nano, vol. 2, no. 11, pp. 2263-2272, 2008. 

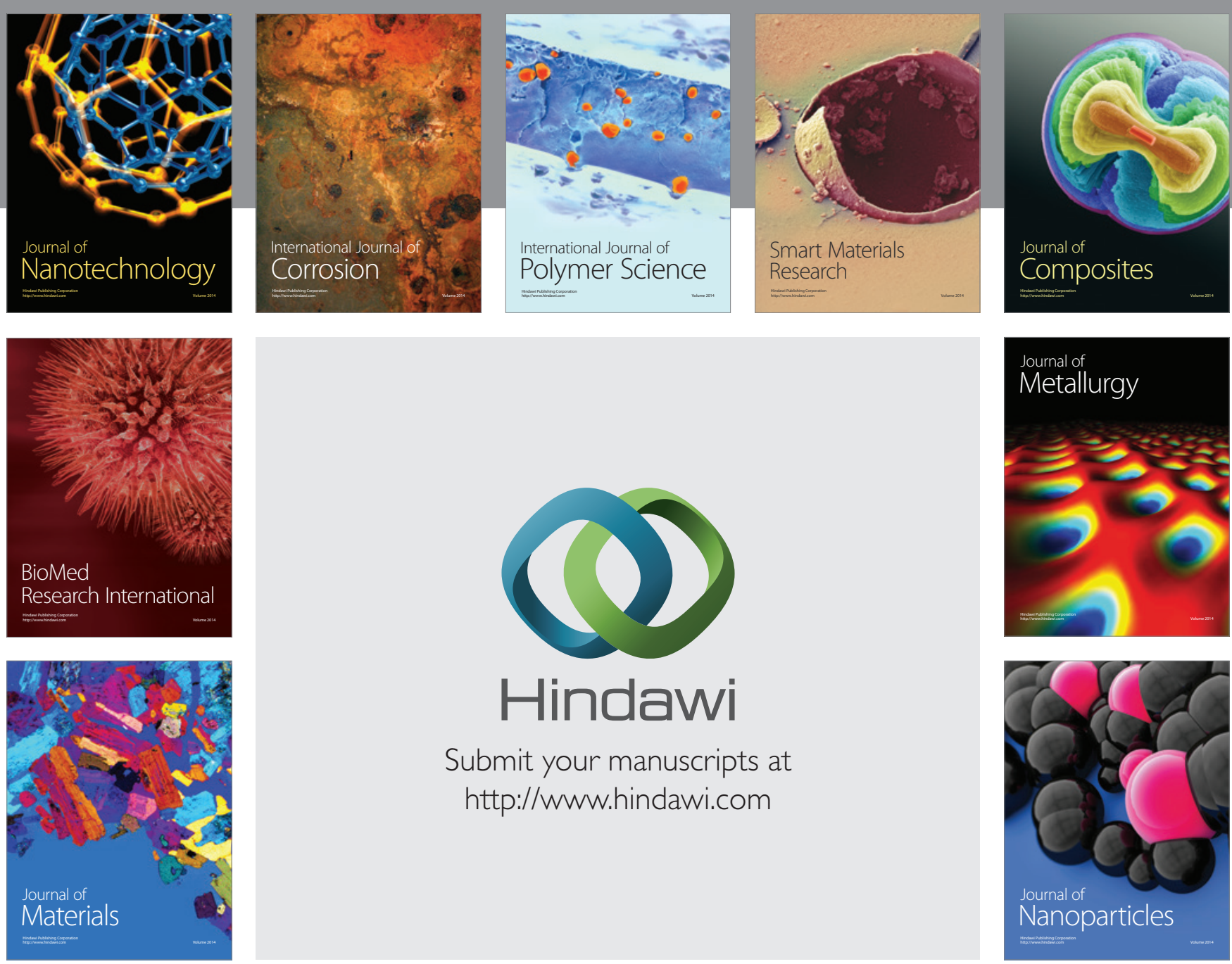

Submit your manuscripts at http://www.hindawi.com
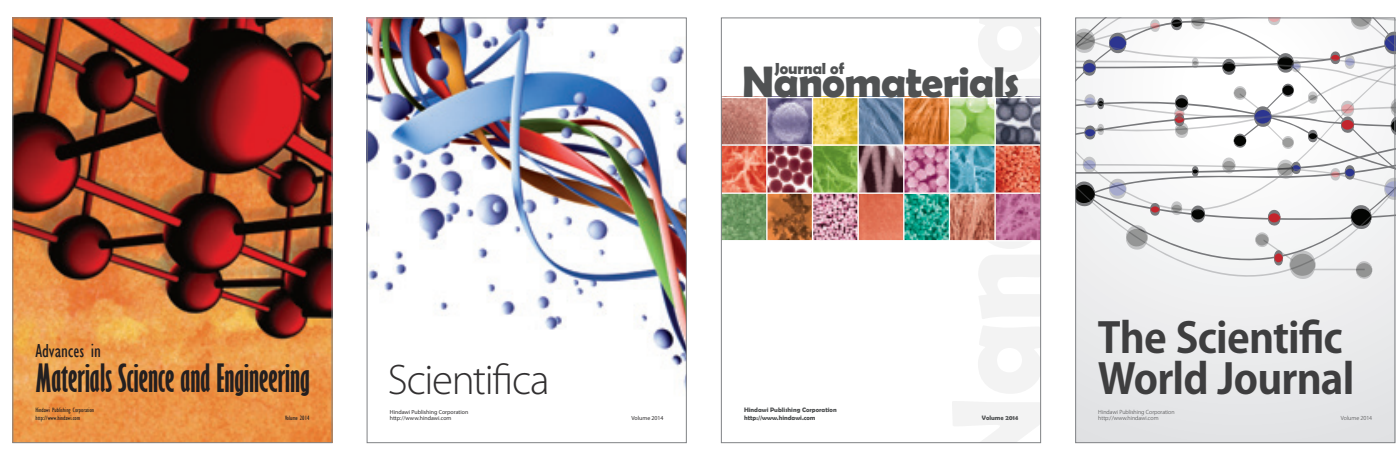

\section{The Scientific World Journal}
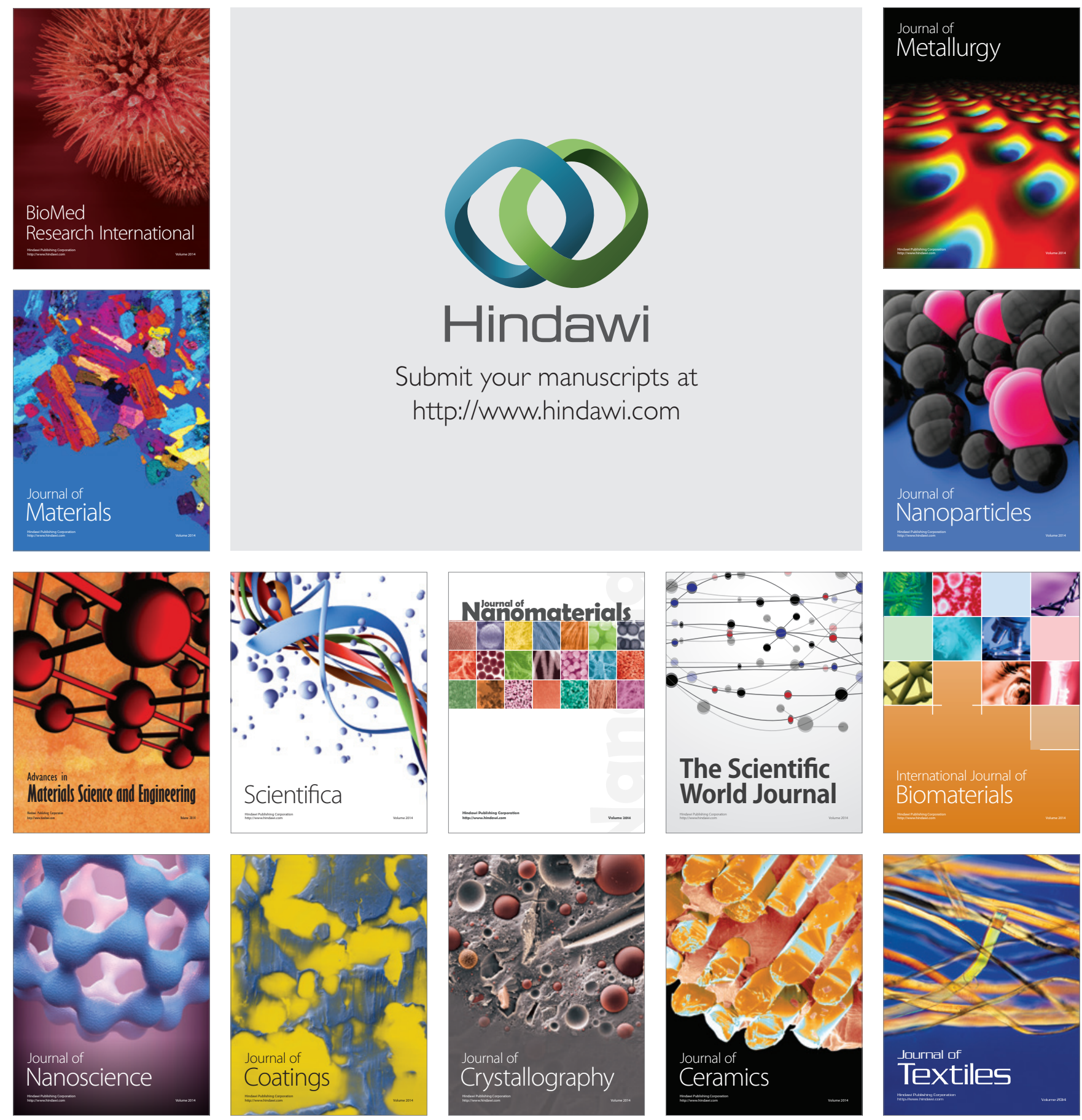